\title{
Okuma Güçlüğünü Gidermede Nörolojik Etki Yönteminin Rolü
}

\section{The Role of Neurological Effect Method in Overcoming Reading Difficulties}

\author{
Murat ŞAHIN ${ }^{a}$, Muhammet BAŞTUĞb
}

Öz

Bu araştırmada görsel, işitsel ve zihinsel herhangi bir problemi olmayan bir üçüncü sınıf öğrencisinin okuma ve okuduğunu anlama problemi, nörolojik etki yöntemi ile giderilmeye çalıșılmıștır. Araștırmada durum çalışması desenlerinden bütüncül tek durum deseni kullanılmıştır. Seçilen öğrencinin herhangi bir görsel, işitsel ve zihinsel probleminin olmadığından emin olduktan sonra öğrencinin okuma ve anlama düzeyini belirlemek için ön test yapılmıștır. Yapılan ön test sonucunda öğrencinin endișe düzeyinde olduğu tespit edilmiştir. Veri toplama aracı olarak "Hızlı Kelime Tanıma Tabloları," "Araştırmacı Gözlem ve Notları", "Hikâye Edici Okuma Metinleri" ve "Yanlış Analizi Envanteri" kullanılmıştır. Öğrencinin okuma sırasında heceleme hataları yaptığı, okuma hızının çok yavas olduğu, akıcı okuyamadığı, yanlıs okuduğu ve atlayıp geçtiğ tespit edilmiştir. Öğrencinin okuma beceri düzeyi dikkate alınarak bireyselleştirilmiş bir okuma programı hazırlanmıștır. Program 48 saatlik bir süreyi kapsamakta olup her bir oturum bir saatlik dilimlerden oluşmaktadır. Çalıșmanın her bir oturumu iki bölüm halinde gerçekleștirilmiștir. Birinci bölümde öğrenciye okunacak metinde en sık tekrarlanan kelimelerin yer aldığı, farklı desenlerde hazırlanmış "Hızlı Kelime Tanıma Tabloları" verilerek okuma çalıșması yapılmıștır. İkinci bölümde ise öğrenci ile birlikte "Nörolojik Etki Yöntemine" uygun olarak okuma çalışması gerçekleştirilmiştir. Çalışmanın sonunda araştırmacı tarafından yapılan son testte öğrencinin okuma ve anlama düzeyinin endişe düzeyinden öğretim düzeyine çıktığı belirlenmiștir

Anahtar Kelimeler: Akıcı Okuma, Nörolojik Etki Yöntemi, Okuma Güçlüğü

\begin{abstract}
In this study, the problem of reading and reading comprehension of a third grade student who does not have any visual, auditory and mental problems was tried to be solved with the neurological effect method. The holistic single case pattern, one of the case study designs, was used in the study. After making sure that the selected student did not have any visual, auditory and mental problems, a pre-test was conducted to determine the reading and comprehension level of the student. As a result of the pre-test, it was determined that the student was at anxiety level. "Quick Word Recognition Tables", "Researcher's Observations and Notes", "Narrative Reading Texts" and "Mistake Analysis Inventory" were used as data collection tools. It was determined that the student made spelling mistakes during reading, his reading speed was very slow, he could not read fluently, he read incorrectly and skipped. An individualized reading program was prepared considering the reading skill level of the student. The program covers a period of 48 hours and each session consists of one hour. Each session of the study was conducted in two parts. In the first part, the reading study was carried out by giving the student "Quick Word Recognition Tables" prepared in different patterns, which include the most frequently repeated words in the text to be read. In the second part, a reading study was carried out in accordance with the "Neurological Effect Method" with the student. At the end of the study, in the post-test conducted by the researcher, it was determined that the student's reading and comprehension level increased from anxiety level to education level.
\end{abstract}

Keywords: Fluent Reading, Neurological Impact Method, Reading Disability

\section{Makale Hakkında}

Tür: Araștırma

Geliş Tarihi: 21 Ekim 2020

Kabul Tarihi: 9 Aralık 2020

Yayın Tarihi: 16 Aralık 2020

DOI: $10.31805 /$ acjes.814139

Sorumlu Yazar:

Murat ŞAHIN

Milli Eğitim Bakanlığı

Türkiye

E-posta: murat4324512747@gmail.com

\section{Önerilen APA Atıf Biçimi / Suggested APA Citation}

Şahin, M., \& Baştuğ, M. (2020). Okuma güçlüğünü gidermede nörolojik etki yönteminin rolü. Academy Journal of Educational Sciences, 4(2), 93-101. http://dx.doi.org/ 10.31805/acjes.814139

aMurat ŞAHIN-ORCID: https://orcid.org/0000-0001-8960-5636

Milli Eğitim Bakanlığı, Turkiye. E-posta: murat4324512747@gmail.com

Ministry of National Education, Turkey. E-mail: murat4324512747@gmail.com

bMuhammet BAȘTUĞ-ORCID: https://orcid.org/0000-0002-5949-6966

İstabul Üniversitesi-Cerrahpașa, Eğitim Fakültesi, Temel Eğitim Bölümü, İstanbul, Turkiye. E-posta: mbastug@istanbul.edu.tr

ìstanbul University-Cerrahpaşa, Faculty of Education, Department of Elementary Education, ìstanbul, Turkey. E-mail: mbastug@istanbul.edu.tr 


\section{Giriş}

Okuma insanların yaşamlarını etkileyen, anlam kazandıran ve çevreleriyle etkileşimlerini sağlayan temel bir beceridir. $\mathrm{Bu}$ becerinin insanlara kazandırılması ve sürdürülebilmesi toplumsal bir zorunluluk olarak görülmektedir. insanlar okuma vasıtası ile hep bir arayış içerisinde uzun bir yolculuğa çıkarlar. Kimi zaman ufak bir heyecan kimi zaman hayati bir bilgi barındıran okuma süreci, hayatın vazgeçilmez unsurlarından biri olarak yașamın her alanında kendini göstermektedir. Hayatın her anında gerçekleşen okuma etkinliği son derece karmaşık ve özel bir zihinsel yapıya sahip olduğu için tanımlanması oldukça zordur. Bununla birlikte alan yazında okuma ile ilgili farklı tanımlar yer almaktadır (Akyol, 2006a). Bu tanımların (Akyol, 2006a; Demirel,1999; Yalçın, 2002; Gündüz ve Şimşek, 2013) her biri okuma kavramını farklı perspektiflerden ele alarak incelemektedir. Yapılmıs olan bu tanımlar okumanın fiziksel, zihinsel ve etkileşimsel bir süreç olduğunu göstermektedir. Bu nedenle okuma etkinliği incelenirken bu süreci etkileyen birçok faktörün varlığı dikkate alınmalıdır. Özellikle okuma güçlüklerinin belirlenmesi ve giderilmesine yönelik yapılacak olan çalışmalarda bireylerin bu faktörlerden etkilenme durumu iyi analiz edilmelidir.

Okuma güçlüğü; bireyin normal veya üstün bir zekâ seviyesine sahip olmasına rağmen beklenilenden daha düşük bir seviyede okuma performansı göstermesidir (Sucuoğlu, Diken, Demir, Ünlü ve Şen, 2010). Bu performans seviyesi bireyin yaş ve zekâ düzeyi dikkate alındığında, doğru okuma, hız ya da okuduğunu anlamada beklenenin altında gösterdiği bir yetersizlik durumudur (American Psychiatric Association, 2013). Okuma güçlüğü olan bireyler yavaş okuma, yetersiz anlama, sesli okuma sorunları ve yetersiz yazılı anlatımlar (Fielding-Barnsley, 2000) sergilemektedirler. Özellikle akıcı okuma becerisi kazanamayan bireylerde bu sorunlar sıklıkla görülmektedir (Therrien, Gormley ve Kubina, 2006).

Akıcı okuma bireyin metinden anlam çıkarmasını sağlayan doğru ve hızlı sözcük okuma becerisidir (Pikulski ve Chard, 2005). Akıcı okuma konusunda ilk çalışmaları yapan araştırmacılardan Huey (1968) akıcı okumayı "bir metni uygun doğruluk, hız ve tonlamayla sesli okuma yeteneği" olarak tanımlamıştır (akt: Baştuğ, 2012). Bireyin akıcı okuma becerisini kazanabilmesi için ihmal edilmemesi gereken ve alan yazında kabul edilen üç temel bileșen; doğru okuma (kelime tanıma), okuma hızı (kelime tanımada otomatikleşme) ve prozodidir (Allington, 1983; Başaran, 2013; Baştuğ, 2012; Hasbrouck ve Tindal, 2006; Keskin, 2012; Klauda ve Guthrie, 2008; Kuhn, 2005). Bu temel bileşenlerden doğru okumayı Ehri ve McCormick (1998) kelimeyi doğru tanıma ve sesleri doğru birşekilde çözümleme becerisi olaraktanımlamaktadır. Kelimelerin ve bu kelimeleri oluşturan birimlerin doğru tanınması, çözümlenmesi ve ayırt edilmesi akıcı okumanın ilk basamağı olarak görülmektedir. Akıcı okumanın diğer önemli bir bileşeni okuma hızıdır. Okuma hızı metinde yer alan her kelimenin tanınması, metnin takılmadan ve hızlı bir şekilde anlaşılarak okunması ve kurulan anlamın zihinden takip edilmesidir (Stahl ve Kuhn, 2002). Okuma hızının artması kelime tanıma becerisine dayanmaktadır. Bireylerin kelime tanımada otomatikleșmeleri okuma hızlarını artırmakta ve çok az bir zihinsel çabayla yapılan okuma etkinlikleri zahmetsiz ve hızlıca gerçekleşmektedir. Akıcı okumanın bir diğer bileşeni prozodidir. Konuşma dilinin müziği olarak ifade edilen prozodi, metni ifade edici bir ritim ve uygun ses tonu içerisinde, anlamına dikkat ederek okumaktır (Dowhower, 1991; akt: Baştuğ, 2012). Bu üç bileşene uygun olarak yapılan okumalar akıcı okuma kapsamında değerlendirilmektedir.
Okuma güçlüğü yaşayan bireylerde bu temel bileşenlerin yeterince gelişmediği görülmektedir. Kelime tanıma becerisi gelişmeyen bireylerden hızlı okuma ve prozodik okuma beklenmemektedir. Bu nedenle öncelikli olarak bireyin kelime tanıma becerisini kazanmasına yönelik çalışmalar gerçekleştirilmelidir. Kelimetanımabecerisigelişenbireylerde yapılacak sistemli çalışmalar ile otomatikleşme sağlanabilir. Okumada otomatikleşen bireylerde yapılacak olan prozodik okuma çalışmaları ile bireyin akıcı okuma becerisi geliştirilir. Prozodik okuma çalışmalarına başlamadan önce bireyin okumada belirli bir hız ve doğruluğu yakaladığından emin olmak gerekir. Çünkü okumada belli bir hızı ve doğruluğu yakalamayan bireylerin prozodik okuma yapmaları mümkün değildir. Prozodik okuma temelde metni anlamayı gerektiren bilişsel bir süreçtir (Keskin, 2012).

Okuma güçlüğü çeken bireylerin okumalarını düzeltmek için herhangi bir müdahale yapılmazsa, hayat boyu okumayla ilgili bu problemlerle yaşayacaklardır (Yılmaz, 2008). Bu nedenle okuma güçlüğü çeken öğrencilerin okuma sorunlarının tespit edilmesi ve bu sorunlara yönelik alternatif yöntemlerin uygulanması gerekir. Literatürde okuma alanındaki güçlüklerin giderilmesi ve akıcı okuma becerisinin geliştirilmesine yönelik birçok yöntem yer almaktadır. Tekrarlı okuma, arkadaşla okuma, koro halinde okuma, eşli okuma, yankılı okuma ve okuyucu tiyatroları gibi yöntemler bunlardan bazılarıdır.

Okuma alanındaki güçlüklerin giderilmesi ve akıcı okuma becerisinin geliştirilmesine yönelik uygulanan yöntemlerden birisi de Nörolojik Etki Yöntemi'dir (NEY). Nörolojik Etki Yöntemi, bir öğretmen ve öğrencinin bire bir ve aynı anda (bir ağızdan) okumasıyla yapılan bir akıcı okuma yöntemidir. Koro, eko ve eşli okuma ile benzerlikler gösteren destekli okumanın bir türüdür (Rasinski, 2010; akt Baștuğ ve Kaman, 2013). Nörolojik etki yöntemi Heckelman'ın (1966-1967; akt. Flood, Lapp ve Fisher, 2005) çalışmalarına dayanmaktadır. Heckelman tarafından ortaya atılmış olan bu yöntem çok fazla duyu organının kullanımasını gerektiren bir yaklaşım olarak görülmektedir. Nörolojik etki yöntemiyle gerçekleştirilen bir okuma çalışmasında öğrenci öğretmeni ile birlikte aynı anda kelimeleri görür, seslendirir, seslendirdiği kelimeleri işitir ve parmağı ile takip ederek metni okur. Birden çok duyu organını harekete geçiren bu yöntemin okuma güçlüklerinin giderilmesinde ve akıcı okuma becerisinin kazandırılmasında etkili bir yöntem olduğu söylenmektedir (Flood vd., 2005: Kann, 1983).

Nörolojik etki yöntemi özellikle 1960 -1990 yılları arasında yoğun bir şekilde kullanılmıştır. Nörolojik etki yöntemi 2005 (Flood vd.) ve 2013 ( Baştuğ ve Kaman) yıllarında yapılan çalışmalar ile yeniden literatürde yer almaya başlamıştır. Alan yazındaki kaynaklara (Flood vd., 2005; Kaşkaya, 2015) göre nörolojik etki yönteminin uygulanma süreci aşağıdaki şekilde sıralanabilir:

\section{•Öğrencinin düzeyine uygun bir metin seçilir. \\ - Öğretmen öğrencinin daha iyi duyabilmesi için} yanına oturur.

- Öğretmen ve öğrencinin ișaret parmağı okuma yaparken okuma metni üzerinde eş zamanlı olarak hareket eder.

- Öğretmen öğrenciden biraz daha sesli ve hızlı okur öğrenciye iyi bır model olur.

- Öğrenci kelime tanıma becerissi otomatikleşip okumaya ve anlamaya başladığında öğretmen okuma sırasında öğrencinin öne geçmesine izin verir.

- Uygulama en az sekiz seans devam ettirilir.(Richek vd., 2002; akt. Baştuğ ve Kaman, 2013). 
Okuma güçlüğüyaşayan bireylerin bulundukları ortamlarınve etkileşim halinde bulundukları unsurların farklılaştırılmasına yönelik çabalar devam etmektedir. Bu çabalar doğrultusunda araştırmacılar öğrencileri karakterize eden bireysel, gelişimsel ve bağlamsal farklııkları ortaya çıkaran yeni çalışmalara yönelmektedirler. Bu bağlamda öncelikli olarak okuma güçlüğü yaşayan öğrencilerin, daha zengin fikirlerle meşgul olabilmeleri ve akıl yürütme kapasitelerinde ilerleme sağlayabilmeleri için yaşadıkları kod çözme sorunlarının en aza indirilmesi gerekmektedir (Ülper ve Yağmur, 2016). $\mathrm{Bu}$ sorunun giderilmesine yönelik olarak uygulanan sınıf içi öğretim uygulamaları geleneksel uygulamalara karşı daha başarılı bulunmaktadır. Çünkü bu uygulamalar çocukların kişisel öğretimini benimseyen, sosyal-duygusal ihtiyaçlarına yanıt veren ve devam etmekte olan beceri değerlendirmelerine dayanan dinamik çalışmalardır. Bu çalışmalarda okuma güçlüğü yaşayan öğrencilere yönelik olarak öncelikle kod çözme ve kelime tanıma çalışmaları yapılmaktadır. Kod çözme ve kelime tanıma becerisine yönelik çalışmalar öğrencilerde otomatikleşmeye doğru uzanan bir yolun kapısını aralamaktadır (Aktaş ve Çankal, 2019). Literatürde bu amaç doğrultusunda gerçekleştirilen birçok çalışma yer almaktadır. Ancak bu çalışmalar içerisinde nörolojik etki yönteminin hızlı kelime tanıma tabloları ile desteklenmiş olduğu herhangi bir çalışmaya rastlanmamıştır. Hızlı kelime tanıma tabloları bireylerde kelime tanıma becerisinin gelişimine büyük katkı sağlamaktadır. Nörolojik etki yönteminin bu hızlı kelime tanıma tablolarının ile desteklenmesinin okuma güçlüklerinin giderilmesinde daha etkili sonuçlar vereceği düşünülmektedir. Ayrıca nörolojik etki yönteminin belirlenmiş olan bir plan dâhilinde bireysel bir çalışma program olarak uygulanması bundan sonra yapılacak benzer çalışmalara yol gösterici olacaktır.

Bu çalışma ile zihinsel, ișitsel ve görsel hiçbir engeli olmamasına rağmen okuma güçlüğü çeken bir öğrencinin okuma ve okuduğunu anlama problemlerinin giderilmesi amaçlanmıştır. Bu amaç doğrultusunda öğrenciye özgü hazırlanmış bireyselleştirilmiş okuma programı çerçevesinde "Nörolojik Etki Yöntemi" ve "Hızlı Kelime Tanıma Tabloları"nın okuma güçlüklerinin giderilmesinde ne derecede etkili olduğu belirlenmeye çalışılmıştır.

\section{Yöntem}

Araştırmanın bu bölümünde araştırmanın yöntemine. katılımcı bilgilerine, veri toplama araçlarına ve veri analizlerine ilişkin bilgilere yer verilmiştir. Ayrıca katılımcının yapmış olduğu hatalar açık bir şekilde belirtilerek çalışmanın geçerlilik ve güvenirliliği artırılmaya çalışı mıştır.

\section{Araştırma Modeli}

Araştırmada durum çalışması desenlerinden bütüncül tek durum deseni kullanıımıştır Durum çalışmaları araştırmacının kontrol edemediği bir olgu ya da olayı 'nasıl' ve 'niçin' sorularını ön planda tutarak derinliğine incelenmesine imkan tanır. Bütüncül tek durum deseni, araștırmacıya tek bir analiz öğesini (birey, okul, durum vb.) ele alarak çalışma imkanı sunar (Yıldırım ve Şimşek, 2016). Bu çalışmada öncelikle öğrencinin okuma ve okuduğunu anlama güçlükleri tespit edilmiş ve bu güçlüklerin giderilmesine yönelik bir okuma programı hazırlanmıştır. Bu programda öğrencinin okuma alanındaki yetersizliklerini ortadan kaldırmak amacıyla "Nörolojik Etki Yöntemi" (Neurological Impress Method) ve hızı kelime tanıma tabloları kullanılarak 48 saatlik bir uygulama yapılmıştır. Gerçekleştirilen uygulamalar birer saatlik zaman dilimlerinden oluşmaktadır. Bu bir saatlik uygulamaların ilk bölümü(yirmi dakika) hızı kelime tanıma tablolarına, ikinci bölümü(yirmi dakika) nörolojik etki yöntemine dayalı okuma çalışmalarına ayrımıştır. Her iki bölüm arasında kalan yirmi dakikalık sürede ise çeşitli etkinliklere(yapboz çalışması, pastel boya çalışması, mangala, futbol, basketbol) yer verilmiştir.

\section{Katılımcı Bilgileri}

Araştırmacı öncelikle Van ilindeki A okuluna (etik nedenlerden dolayı okul ve öğrenci ismi gizlenmiştir) gitmiş ve okul müdürü ile araştırma konusu ile ilgili görüşmüştür. Okul müdürü okuma güçlüğü çeken öğrencilerin olup olmadığına yönelik öğretmenler ile görüşmüș ve üçüncü sınıf öğrencilerinde okuma güçlüğü yaşadığı düşünülen beş öğrenci belirlenmiştir. Belirlenen öğrencilere araștırmacı tarafından kendi sınıf düzeylerine uygun metinler okutturularak okuma güçlüğünün olup olmadığı belirlenmeye çalışılmıştır. Bu beş öğrenciden üçü okuma güçlüğü yaşamadıkları belirlenince araștırmacı tarafından elenmiștir. Daha sonra geriye kalan iki öğrenciye kendi düzeylerine uygun metinler okutturulmuş ve okumalar kayıt altına alınmıştır. Ses kayıtları alan uzmanları ile birlikte incelenerek değerlendirilmiştir. Bu kayıtların incelenmesi sonucunda bir öğrencinin okuma güçlüğü yaşadığı kesinleştirilerek çalışılacak katılımcı belirlenmiştir. Ögrencinin gerçek ismi etik nedenlerden dolayı gizlenmiş olup "Ali" kod adı ile araştırmada isimlendirilmiştir.

Ali beş çocuklu bir ailenin en küçük çocuğudur. Ali'nin sürekli bir hastalığı olmamakla birlikte herhangi bir zihinsel ve fiziksel engeli bulunmamaktadır. Ali'nin babası inşaat işçisi ve annesi ev hanımıdır. Ailenin ekonomik durumu düşük düzeyde olup oturdukları ev kendilerine aittir. Ali'nin kendine ait bir çalışma odası bulunmamakta ve oturdukları ev sobalıdır. Ali'nin babası ilkokul mezunudur. Ali'nin annesi ise okuma yazma bilmemektedir. Ali'nin iki abisi ve bir ablası ortaokul eğitiminden sonra okula devam etmemişlerdir. Ali'nin bir abisi ise şu an yedinci sınıfta eğitim görmektedir. Ali ilkokul birinci sınıfta başka bir öğretmen tarafından okutulmus ve okumayı sene sonuna doğru öğrenebilmiştir. Ali'yi ikinci sınıftan sonra okutmaya başlayan şu andaki mevcut sınıf öğretmeni Ali'nin ikinci sınıfın ilk döneminde harfleri tanımakta bile zorlandığını ifade etmiştir. Sınıf öğretmeni, Ali ile okuma çalışmaları yapmak için çabaladığını ancak sınıf mevcudunun kalabalık olmasından dolayı planlı bir çalışma yürütemediğini belirtmiştir. Sınıf öğretmeni Ali'nin derse karşı motivasyonunun çok düşük olduğunu ve sınıfta öğrenci mevcudunun fazla olmasından dolayı Ali ile bireysel ilgilenmeye çok vakit kalmadığını belirtmiştir. Sınıf öğretmeni Ali'nin derslerde sessiz ve içine kapanık ve ev ödevlerini yapma noktasında problemli davranışlar sergilediğini ifade etmiştir. Sınıf öğretmeni ayrıca Ali'nin ailesinin ders ve ödevler ile pek ilgilenmediklerinden şikâyet etmektedir. Sınıf öğretmeni, Ali'nin teneffüslerde arkadaşları ile olan ilişkilerinde herhangi bir problem yaşamadığını belirtmiştir. Ali'nin annesi ile yapılan görüşmede anne çocuğunun ders çalışma alışkanlığının olmadığını belirtmiştir. Ali'nin okuldan geldikten sonra çok uzun bir süre televizyon izlediğinden şikâyet eden annesi ödevlerini yaptırmakta zorlandığını ifade etmiştir. Ali'nin annesi okuma yazma bilmediğinden Ali'ye yeterince yardımcı olamadığını belirtmiştir. Ali'nin annesi diğer çocuklarında okuma ile ilgili bir problem yaşamadıklarını, bu durumun çocuğun isteksizliği ile ilgili olabileceğini belirtmiştir.

\section{Veri Toplama Araçları}

Bu araştırmada veri toplama araçları olarak " Hikâye Edici Okuma Metinleri", "Hızlı Kelime Tanıma Tabloları", "Okunan Metinlerin Ses Kayıtları", "Yanlıs Analizi Envanteri" ve "Araştırmacıların Gözlem ve Notları" kullanılmıştır. 


\section{Yanlış analizi envanteri}

Ekwall ve Shanker(1988)'in geliştirilmiş olduğu envanter Akyol (2011) tarafından türkçeye uyaralanmıştır. Envanter, kelime bilgisi ve okuduğunu anlama düzeyini tespit etmeye yarayan iki bölümden oluşmaktadır. Bu envanterde okuyuculara sesli ve sessiz okuma yaptırılarak okuma düzeyleri tespit edilmektedir. Envanterin ilk bölümünde öğrenci sesli okuma yaparken araştırmacı aynı metin üzerinden okuyucunun yaptığı hataları semboller ile işaretlemektedir. Okuma sırasında tespit edilen hata sayısı okunan metindeki toplam kelime sayısına bölünerek 100 ile çarpılması sonucunda hata oranı hesaplanır. Örneğin öğrenci 200 kelimelik bir metinde 30 tane hata yaptıysa hata oranı; 30 bölü 200 çarpı 100'e eşittir, yani hata oranı yüzde 15'dir. Belirlenen bu hata yüzdeliğinin dışında kalan oran okumanın doğru okunma yüzdesini (\%100 - \%15=\%85) vermektedir. Doğru okuma yüzdesi belirlendikten sonra öğrenciden aynı düzeyde bir metni sessiz okuması istenmektedir. Öğrenciye okunan metini ile ilgi hazırlanmış olan basit ve derinlemesine sorular yöneltilir. Daha sonra verilen cevaplara göre puanlama yapılır. Basit anlama sorularına verilen cevaplar hiç cevaplanmama(o puan), yarı cevaplanma(1 puan) ve tam cevaplanma (2 puan) durumlarına göre puanlanmaktadır. Benzer şekilde derinlemesine anlama sorularına verilen cevaplar; hiç cevap verilmemesi(o puan), yarı cevap verilmesi(1 puan), beklenen cevabın yarıdan fazlasının verilmesi(2 puan) ve tam ve etkili olarak cevaplanması( 3 puan) durumuna göre puanlanır. Öğrencinin verdiği cevaplar sonucunda aldığı toplam puan sorulardan alınabilecek en yüksek puana bölünür ve 100 ile çarpılarak anlama yüzdesi hesaplanır. Örneğin öğrenci yöneltilen sorulardan toplam 3 puan aldı ve bu sorulardan alınabilecek en yüksek puanın ise 9 olduğunda anlama yüzdesi 3 bölü 9 çarpı 100'e eşittir. Yani anlama yüzdesi \%33 olarak hesaplanır (Demir, 2015). Yanlış analiz envanteri ile üç tür okuma düzeyi tespit edilmektedir. Öğrenci bu düzeyler içerisinde en üst basamağa ulaştığında öğretmenin veya başka bir yetişkinin yardımına intiyaç duymadan düzeyine uygun materyalleri okuyabilir ve okuduğunu anlayabilir. Bu düzey serbest okuma düzeyi olarak adlandırılır. Bu düzeyin bir alt düzeyi olan öğretim düzeyinde öğrenci, öğretmen veya bir yetişkinin yardımı ile istenilen şekilde okuyabilir ve okuduğunu anlayabilir. En alt düzey olan endişe düzeyinde ise öğrenci okuduğunun çok azını anlar veya pek çok okuma yanlışı yapar (Akyol, 2006b) Öğrencilerin kelime tanıma ve anlama düzeylerine göre bulundukları okuma düzeyleri Tablo1'de belirtilmiştir

Tablo 1. Okuma Düzeyleri ve Yüzdelikleri (Ekwall ve Shanker,1998; akt: Akyol, 2011)

\begin{tabular}{lcc}
\hline Okuma Düzeyleri & Kelime Tanıma & Anlama \\
\hline Serbest Okuma Düzeyi & $\% 99+$ & $\% 90+$ \\
\hline Öğretim Düzeyi & $\% 95^{+}$ & $\% 75^{+}$ \\
\hline Endişe Düzeyi & $\% 90-$ & $\% 75-$ \\
\hline
\end{tabular}

\section{Hikâye edici okuma metinleri}

Çalışma için seçilen metinler birinci ve ikinci sınıf ders kitaplarında bulunan ve araştırmacı tarafından hazırlanan hikâye edici okuma metinlerden oluşmaktadır. Bu metinler seçilirken kelime sayıları ve zorluk düzeyleri göz önünde bulundurularak öğrencinin seviyesine uygun olmasına dikkat edilmiştir. Seçilen metinler uzman görüşü alındıktan sonra çalışmalarda kullanılmıştır.

\section{Hızlı kelime tanıma tabloları}

Hızlı kelime tanıma tabloları her sayfasında 10 kelimenin yer aldığı farklı desenlerde hazırlanmış beş tablodan oluşmaktadır. Bu beş tabloda toplam on kelime farklı desenlerde sunulmaktadır. Bu tablolar sayesinde öğrencinin kelimeleri ezberlemeden hızlı tanıması amaçlanmaktadır. Okuma programında yer alan her çalışma için bu tablolardan hazırlanmıştır. Tablolarda yer alan kelimeler o gün okutulacak metinde en sık tekrarlanan kelimelerden seçilmiştir.

\section{Okunan metinlerin ses kayıtları}

Okuma programına geçmeden önce araştırmacı tarafından öğrencinin okuma düzeyinin belirlenmesi amacı ile ses kayıt cihazı kullanımıştır. Ses kayıtları incelenerek öğrencinin okuma hataları ve okuma düzeyi belirlenmiştir. Ayrıca okuma programında uygulanan her sekiz oturumdan sonra öğrencideki değişimi izlemek amacıyla yapılan okuma çalışmalarında ses kayıtları kullanılmıştır. Çalışmanın sonunda yapılan son test çalışmasında da yine ses kaydı yapılmış ve öğrencinin ulaştığı okuma düzeyi tespit edilmeye çalışılmıştır.

\section{Araştırmacının gözlem ve notları}

Araștırmanın bașlangıç aşamasından son aşamasına kadar geçen süre içerisinde araştırmacı tarafından okuma süreci gözlemlenmiş ve notlar alınmıştır. Yapılan bu gözlem çalışmaları ve alınan notlar gelişen süreç hakkında araştırmacıya ciddi dönütler sağlamıştır.

\section{Verilerin Toplanması}

Okuma güçlüğü yaşayan bir öğrencinin okuma ve okuduğunu anlama problemini gidermeye yönelik yapılan bu çalışma; bireyselleştirilmiş okuma programından önce yapılan çalışmalar ve okuma programının uygulanma sürecindeki çalışmalar olmak üzere iki bölüm halinde ele alınabilir. ilk bölüm bireyselleștirilmiş okuma programından önceki yapılan çalışmaları kapsamaktadır. İkinci bölüm ise hazırlanan programın uygulanması sürecinde yapılan çalışmaları kapsamaktadır.

\section{Bireyselleştirilmiş Okuma Programından Önce Yapılan Çalışmalar}

Endişe düzeyinde olduğu tespit edilen öğrencinin mevcut durumu göz önünde bulundurularak düzeyine uygun bir bireyselleştirilmiş okuma programı hazırlandı. Okuma programını hazırlanma sürecinde çalışma süresinin 48 saat olmasına karar verildi. Ayrıca okuma programında kullanılacak öğrenci düzeyine uygun hikâye edici okuma metinler ile bu metinlerde en sık geçen kelimelerden oluşturulmuş olan hızlı kelime tanıma tabloları hazırlandı.

Hazırlanan okuma programı uygulanmadan önce öğrencinin okul müdürü, sınıf öğretmeni, ailesi ve kendisi ile görüşüldü. Okul müdürü ile yapılan görüşmede çalışmada uygulanacak takvim ve program sunularak bu çalışmanın uygulanacağı yer ve saat hakkında kararlar alındı. Okul müdürü ile yapılan görüşme sonucunda çalışmaların hafta içi her gün 13:10-14:10 saatleri arasında öğretmenler odasında yapılmasına karar verildi. Bu saatin belirlenmesinde öğrencinin serbest zaman etkinliği dersinin bu saatte olması göz önünde bulunduruldu ve öğrencinin diğer derslerden geri kalmaması düşünüldü. Öğretmenler odasının o saatlerde boş olduğu ve çalışma için uygun şartları taşıdığı görüldüğünden çalışmanın burada yapılmasına karar verildi. Sınıf öğretmeni ile yapılan görüşmede çalışma hakkında bilgi verildi. Daha sonra öğrencinin genel seviyesi, sınıftaki davranışları, arkadaşları ile ilişkileri, derse katılım durumu, diğer derslerdeki başarı durumu, ders çalışma alışkanlığı ve öğrenci velisinin ilgisi hakkında görüşmeler sağlandı. Sınıf öğretmenine çalışma sürecinde koordineli bir şekilde çalışılması durumunda öğrencinin okuma becerisinin 48 saatlik bir çalışma sonucunda pozitif yönde gelişim gösterebileceği anlatııldı. 
Çalışımmada kullanılacak yöntem ve teknik sınıf öğretmenine bireyselleştirilmiş okuma programı üzerinde ayrıntılı olarak anlatıldı. Araştırmacının teklifi ve sınıf öğretmenin işbirliğine karşı olumlu tutumu neticesinde okuma programında belirtilen çalışmaların haftanın iki gününde (salı, çarşamba) sınıf öğretmeni tarafından diğer günlerde (pazartesi, perşembe ve cuma) araştırmacı tarafından koordineli olarak uygulanacak şekilde planlama yapıldı. Bu şekilde öğrencinin çalışma sürecinde sıkılmadan süreklilik sağlaması amaçlandı. Şınıf öğretmenin çalışmaya karşı ilgili olması ve bu konuda olumlu tavır sergilemesi büyük bir artı değer olarak görüldü. Öğrenci velisi ile yapılan görüşmede çalışma hakkında bilgilendirme yapıldı. Öğrenci velisinin bu durumdan memnun olması ve memnuniyetini dile getirmesi çalışmanın daha sağlıklı yürütüleceği konusunda umutları artırdı. Öğrencinin velisine öğrenciye verilecek ev ödevlerinde nelere dikkat edilmesi gerektiği örnekler verilerek ayrıntılı bir şekilde anlatıldı. Öğrenci ile yapılan görüşmede ise öncelikle öğrencinin güven ve sevgisinin kazanılmasına çalışıldı. Birlikte güzel ve keyifli etkinliklerin yapılacağı belirtildi. Çalışmaların ne zaman ve nerede yapılacağı paylaşıldı. Öğrencinin bu çalışmalardan sıkılmaması için keyifli oyunlar ve etkinliklerin bu çalışmalar arasında yapılacağı belirtilerek çalışmaya odaklanması ve severek katıım sağlaması konusunda yüreklendirildi.

\section{Bireyselleştirilmiş Okuma Programının Uygulanması}

Bireyselleştirilmiș okuma programı 2018-2019 eğitim öğretim yılının ikinci döneminde yürütülmüştür. Çalışmanın başladığı ilk oturumlarda öncelikle öğrencinin güven ve sevgisinin kazanılması amaçlanmıştır. ilk hafta gerçekleştirilen derslerde öğrencinin sıkılmaması için motivasyonunu artırıcı pekiştireçler verilerek çalışmaya karşı motivasyonun yüksek olması sağlanmıștır. Derse başlamadan önce Ali ve öğretmeni ile birlikte çalışılacak öğretmenler odası gezilmiş ve Ali'nin bu ortamda kendini rahat hissetmesi için odanın bu çalışma için tahsis edildiğinden bahsedilmiştir. Bu şekilde öğrencinin öğretmenler odasına karşı varsa çekingenliğinin ortadan kaldırılmasına çalışılmıştır. Öğrenci ve öğretmenin bir arada oldukları bu sürede ayrıca çalışma saatleri ve kullanılacak materyaller tanıtılmıştır. Çalışmalarda oturum süresinin çok uzun olmayacağı, istenildiği zaman oturuma ara verileceği belirtildi. Çalışmanın iki bölüm halinde yapılacağı ve bu iki oturum arasında farklı eğlenceli etkinliklerin yapılacağı anlatıldı. Çalışmaların ilk oturumlarında Ali'nin kelime hazinesinin ve kelime tanıma becerisinin geliştirilmesine yönelik çalışmalar yapıldı. Bunun için Ali'den önceden hazırlanmış olan hızlı kelime tanıma tablolarındaki kelimeleri araştırmacı ile birlikte okuması istendi. Bu çalışmalar her yapıldığında Ali'nin ilk tablolarda biraz zorlandığı ama diğer tablolara geçtiğinde daha hızı ve keyifli okumalar yaptığı görüldü. Ali'nin hızlı kelime tanıma çalışmalarında sıkılmadığı gözlemlendi. Hızlı kelime tanıma tablolarındaki kelimeler öğrenci ile beraber nörolojik etki yöntemine uygun bir şekilde okundu. Hızlı kelime tanıma tabloları ile yapılan çalışmalar ortalama 20 dakikada tamamlandı. Birinci oturum tamamlandıktan sonra öğrenci ile birlikte okuma programında belirlenen keyifli etkinlikler (yapboz çalışması, pastel boya çalıșması, mangala, futbol, basketbol) gerçekleştirildi. Bu etkinliklerin süresinin 20 dakikayı geçmemesine özen gösterildi. Daha sonra ikinci oturumda önceden hazırlanmış olan hikâye edici metinler öğrenci ile birlikte nörolojik etki yöntemine uygun bir şekilde okundu. Bu okumalar sırasında araştırmacı öğrencinin metne bağlı kalmasını sağlayacak bir hızda örnek okumalar gerçekleştirerek farkındalık oluşturdu. Yapılan bu çalışmalar ortalama 20 dakikada tamamlandı. Sesli okuma sırasında araştırmacı Ali'ye hiçbir şekilde müdahale etmedi. Sesli okuma tamamlandıktan sonra araştırmacı tespit ettiği okuma hatalarını Ali ile paylaştı ve bu okuma hatalarının doğrusu sözlü olarak gösterilerek birlikte yeniden okuma yapıldı. Metinler okunduktan sonra okuma metni öğrenciye verilerek evde dört kez anlayarak sesli okuması istendi. Yapılan bu çalışmalar her oturumda tekrarlandı ve uygulanan her sekiz oturumdan sonra öğrencinin doğru okuma ve anlama yüzdesi ölçülerek gelişim düzeyi kontrol edildi.

\section{Etik Beyan}

Yapılan bu çalışmada "Yükseköğretim Kurumları Bilimsel Araştırma ve Yayın Etiği Yönergesi" kapsamında uyulması belirtilen tüm kurallara uyulmuştur. Yönergenin ikinci bölümü olan "Bilimsel Araştırma ve Yayın Etiğine Aykırı Eylemler" başlığı altında belirtilen eylemlerden hiçbiri gerçekleştirilmemiştir.

\section{Bulgular}

Ali'nin okuma düzeyini belirlemeye yönelik olarak ön test çalışması yapılmıştır. Ali'ye ilkokul üçüncü sınıf Türkçe ders kitabında yer alan "İnci" adlı metin sesli okutulmuş ve okuma hataları tespit edilmeye çalışmıştır. Aynı zamanda ses kaydı alınmış olan çalışma incelenmiş ve Ali'nin 158 kelimelik metinde 45 kelimeyi hatalı okuduğu bu nedenle kelime tanıma düzeyinin \%72 olduğu tespit edilmiştir. Okuma hataları ve düzeyine ilişkin sonuçlar Tablo 2.'de sunulmuştur.

Tablo 2. Okuma Hataları ve Düzeyine Iliş̧kin Ön test Sonuçları

\begin{tabular}{lcc}
\hline Okuma Hataları & $\begin{array}{c}\text { Hata } \\
\text { Sayısı }\end{array}$ & $\begin{array}{c}\text { Kelime Tanıma } \\
\text { Yüzdesi }\end{array}$ \\
\hline Eklemeler & 3 & \\
\hline Atlamalar & 2 \\
\hline Tekrarlar & 3 \\
\hline Yanlıs okuma & 29 \\
\hline Öğretmen Tarafından Verilen Kelimeler & 6 & \\
\hline Kendi Kendini Düzeltme & $\% 72$ \\
\hline Toplam & 2 \\
\hline
\end{tabular}

Ali'ye daha sonra aynı düzeyde olan üçüncü sınıf Türkçe ders kitabındaki "Timur'un Filleri" adlı metin sessiz okutulmuş ve anlama düzeyi tespit edilmeye çalışılmıştır. Ali'ye sorulan basit ve derinlemesine sorular neticesinde alınan cevaplar puanlanmış ve Ali'nin 3 (üç) puan aldığı görülmüştür. Bu puan Ali'nin okuduğunu anlama düzeyinin \% 25 olduğunu göstermiştir. Anlama düzeyini ölçen sorular ve verilen cevaplar Tablo 3'te sunulmuştur.

Okuma ve okuduğunu anlama seviyesini belirlemek amacı ile ön test olarak uygulanan yanlış analizi envanterine göre Ali'nin okuma düzeyinin endişe düzeyinde olduğu belirlenmiştir. Yapılan ön test sonuçları özet olarak Tablo 4'te sunulmuştur.

Ali'nin kelime tanıma ve anlam yüzdesi Ali'nin endişe düzeyinde olduğunu göstermiştir. Ali'nin sesli okuma sürecinde birçok okuma hatası yaptığı, okuma hızının çok düşük olduğu ve akıcı okuyamadığı tespit edilmiştir. Ali'nin ayrıca okuduğunu anlamada ciddi düzeyde problem yaşadığı tespit edilmiştir.

Ali'nin okuma ve okuduğunu anlama düzeyini artırmak için uygulanan okuma programı sonrasında meydana gelen değişimi belirlemeye yönelik olarak son test çalışması yapılmıştır. Ali'ye ilkokul üçüncü sınıf Türkçe ders kitabında yer alan "Son Pişmanlık" adlı metin sesli okutularak okuma 
Tablo 3. "Timur'un Filleri" Adı Metin Ile Anlama Düzeyini Belirlenmeye Yönelik Ön Test Sonuçları

\begin{tabular}{|c|c|c|c|c|c|}
\hline Sorular & Soru türü & $\begin{array}{c}\text { Öğrencinin verdiği } \\
\text { cevaplar }\end{array}$ & $\begin{array}{l}\text { Alınan } \\
\text { Puan }\end{array}$ & $\begin{array}{l}\text { Alınması Gereken } \\
\text { Toplam Puan }\end{array}$ & $\begin{array}{l}\text { Anlama } \\
\text { Yüzdesi }\end{array}$ \\
\hline Timur Akşehir'e hangi hayvanı getirmiş? & Basit anlam (2) & "Fil getirmiş." & 2 & \multirow{6}{*}{12} & \multirow{6}{*}{$\% 25$} \\
\hline Akşehirliler Nasrettin Hoca'dan ne istemiş? & Basit anlam (2) & "Görüşmek" & 0 & & \\
\hline Nasrettin Hoca Timur'dan hangi fili istemiş? & Basit anlam (2) & "Yeni fili" & 1 & & \\
\hline Ahali Nasrettin Hoca'yı neden yalnız bırakmış? & Derin anlam (3) & "Küsmüşler. " & 0 & & \\
\hline Nasrettin hoca ahaliye nasıl ders vermiş? & Derin anlam (3) & "Müjde vermiş," & 0 & & \\
\hline Toplam & & & 3 & & \\
\hline
\end{tabular}

Tablo 4. Yanlış Analiz Envanteri Ile Yapılan Ön test Sonuçları

\begin{tabular}{ccccc}
\hline Metindeki Kelime Sayısı & Hata Sayısı & Kelime Tanıma Yüzdesi & Anlama Yüzdesi & Okuma Düzeyi \\
\hline 158 & 45 & $\% 72$ & $\% 25$ & Endişe Düzeyi \\
\hline
\end{tabular}

Tablo 5. Okuma Hataları ve Düzeyine İlişkin Son Test Sonuçları

\begin{tabular}{ccc}
\hline Okuma Hataları & Hata Sayısı & Kelime Tanıma Yüzdesi \\
\cline { 1 - 2 } Eklemeler & 1 \\
\hline Atlamalar & 0 \\
\hline Tekrarlar & 0 \\
\hline Yanlıs okuma & 7 \\
\hline Öğretmen Tarafından Verilen Kelimeler & 0 \\
\hline Kendi Kendini Düzeltme & 0 \\
\hline Toplam & 8 \\
\hline
\end{tabular}

hataları tespit edilmeye çalışmıştır. Aynı zamanda ses kaydına alınan çalışma incelenmiş ve Ali'nin 159 kelimelik bir metinde 8 (sekiz) kelimeyi hatalı okuduğu, bu nedenle kelime tanıma yüzdesinin \% 95 olduğu tespit edilmiștir. Okuma hataları ve düzeyine ilişkin sonuçlar Tablo 5.'te sunulmuştur.

Ali'ye daha sonra aynı düzeyde olan üçüncü sınıf Türkçe ders kitabındaki "Her Şeye Rağmen" adlı metin sessiz okutulmuş ve anlama düzeyindeki değişim tespit edilmeye çalışılmıştır. Ali'ye sorulan basit ve derinlemesine sorular neticesinde alınan cevaplar puanlanmış ve Ali'nin 10 (on) puan aldığı görülmüştür. Bu puan Ali'nin okuduğunu anlama düzeyinin \% 83 olduğunu göstermiştir. Anlama düzeyini ölçen sorular ve verilen cevaplar Tablo 6'da sunulmuştur.

Ali'nin okuma ve okuduğunu anlama düzeyindeki değişimi belirlemek amacı ile son test olarak uygulanan yanlış analizi envanterine göre Ali'nin okuma düzeyinin öğretim düzeyine ulaştığı tespit edilmiştir. Yapılan son test sonuçları özet olarak Tablo 7'de sunulmuştur.

Tablo 7.'de görüldüğü üzere Ali'nin kelime tanıma ve anlama yüzdesinde ciddi artış sağlanmıştır. Çalışmada Ali'nin daha az okuma hatası yaptığı ve okuduğunu anlamada ilerleme kaydettiği tespit edilmiştir.

\section{Tartışma, Sonuç ve Öneriler}

Yapılan bu çalışmada ilkokul üçüncü sınıftaki bir öğrencinin (Ali) yaşadığı okuma güçlüklerinin nörolojik etki yöntemi ile giderilmesine çalışıımıştır. Bu amaç doğrultusunda uygulanan kırk sekiz saatlik okuma programında hızı kelime tanıma tabloları ile desteklenmiş Nörolojik Etki Yöntemi kullanılmıştır. Kullanılan bu yöntem ve hızlı kelime tabloları

Tablo 6. "Her Şeye Rağmen" Adı Metin Ile Anlama Düzeyini Belirlenmeye Yönelik Son Test Sonuçları

\begin{tabular}{|c|c|c|c|c|c|}
\hline Sorular & Soru türü & Öğrencinin verdiği cevaplar & $\begin{array}{l}\text { Alınan } \\
\text { Puan }\end{array}$ & $\begin{array}{l}\text { Alınması Gereken } \\
\text { Toplam Puan }\end{array}$ & $\begin{array}{l}\text { Anlama } \\
\text { Yüzdesi }\end{array}$ \\
\hline Taylan eve dönerken kime yardım etmiş? & Basit anlam (2) & "Yaşlı adama" & 2 & \multirow{6}{*}{12} & \multirow{6}{*}{$\% 83$} \\
\hline Yaşlı adamın mesleği neymiş? & Basit anlam (2) & "Doktormuş" & 2 & & \\
\hline Yaşlı adam neden mesleğinde ayrılmış? & Basit anlam (2) & "Gözleri kör olmuş." & 2 & & \\
\hline Başkalarına yardım etmenin faydaları nelerdir? & Derin anlam (3) & "Yorulmazlar, sevinirler." & 2 & & \\
\hline Okul arkadaşlarımıza nasıl yardım edebiliriz? & Derin anlam (3) & "Çantasını taşırız, ona kızmayız." & 2 & & \\
\hline \multicolumn{3}{|c|}{ Toplam } & 10 & & \\
\hline
\end{tabular}

Tablo 7. Yanlış Analiz Envanteri Ile Yapılan Son test Sonuçları

\begin{tabular}{ccccc}
\hline Metindeki Kelime Sayısı & Hata Sayısı & Kelime Tanıma Yüzdesi & Anlama Yüzdesi & Okuma Düzeyi \\
\hline 159 & 8 & 95 & 83 & Öğretim Düzeyi \\
\hline
\end{tabular}


ile Ali'nin kelime tanıma becerisinde otomatikleșmesi ve okuduğunu anlama becerisinin geliștirilmesi amaçlanmıştır. Hızlı kelime tanıma tabloları, Ali'nin kelime tanımada otomatikleşmesine yönelik bir uygulama olarak çalıșmaya dâhil edilmiştir. Çalışmada yer alan bu hızı kelime tanıma tabloları ile Ali'nin kelimeleri ezberlemeden hızlı bir șekilde tanıması amaçlanmıştır. Araştırmada kullanılan nörolojik etki yönteminin, çok duyulu bir yaklaşım olarak Ali'nin çalışma sürecinde daha aktif bir şekilde yer almasını imkân sağladığı tespit edilmiștir. Nörolojik etki yönteminin okuma ve okuduğunu anlama üzerindeki etkililiği literatürde yer alan birçok çalışma (Barden, 2009; Eldredge, 1990; Feazell, 2004; Flood vd., 2005; Hollingsworth, 1978; Kann, 1983; King, 1986; Oladede, 2013; Sosoka, 1981; Stanley, 2009; akt: Baştuğ ve Kaman, 2013; Wilson, 1969; Young, Mohr ve Rasinski, 2015; Young, Pearce vd., 2018; Ziadat ve Awan, 2018) tarafından desteklenmektedir. Nörolojik etki yönteminin hızlı kelime tanıma tabloları ile desteklenmesi, çalıșmayı daha önce yapılmış olan benzer çalışmalardan farklılaştırarak zenginleştirmiştir.

Araștırmada Ali'nin okuma ve okuduğunu anlama düzeyi belirlendikten sonra öğrenme güçlüklerinin giderilmesine yönelik bireyselleștirilmiș eğitim planı hazırlanmıștır. Ali'nin okuma ve okuduğunu anlama düzeyini belirlemeye yönelik olarak yapılan ön test çalıșmasında kelime tanıma becerisinin zayıf olduğu, çok fazla okuma hatası yaptığı ve okuduğunu anlamada ciddi problemler yaşadığı tespit edilmiștir. Sıralanan bu sorunlar okuma programının hazırlanma sürecinde göz önünde bulundurulmuş ve bu doğrultuda okuma metinleri seçilmiştir. Uygulanan okuma programı ile Ali'nin kelime tanıma becerisinde ciddi ilerlemeler kaydedilmiștir. Çalışmanın ilk oturumlarında istenilen düzeyde ilerleme sağlanamamasına rağmen Ali'nin okumaya karşı olan ön yargılarının giderilmesi ile sonraki oturumlarda daha fazla ilerleme sağlanmıştır. Bu durum çalışma için bir dönüm noktası olarak görülmektedir. Çünkü Ali, sessiz ve içine kapanık bir çocuk olarak özgüven sorunu yaşamaktaydı. Ali bu nedenle okumaya karşı olumsuz bir tavır sergilemekteydi. Ali ile birebir ilgilenilmesi, okuma çalısmalarının takdir edilmesi ve olumlu pekiștireçlerin sunulması mevcut durumun değişmesinde etkili olmuş olabilir. Ali'nin okumaya karșı olan bu olumsuz tutumu yavaş yavaş giderilmiş ve okumaya karşı olumlu bir motivasyon içerisine girmesi sağlanmıștır. Öğrencinin okuma motivasyonundaki değişim okuma akıcılığı kazanmasında önemli bir etkiye sahiptir. Literetürde bu tezi destekleyen bir çok çalışma(Baker ve Wigfield, 1999; Wang ve Guthrie, 2004; Yıldız, 2013) yer almaktadır. Uygulanan nörolojik etki yönteminin çok duyulu biryaklașım olması Ali'nin uygulamalar sırasında sürekli olarak aktif olmasını sağlamıştır. Uygulanan okuma programı sonrasında Ali'nin okuma hatalarında ciddi azalmalar olmuștur. Ali'nin kelimeleri otomatik olarak okuyabildiği görülmüștür. Okuma hızında istenilen düzeye ulaşılamamasına rağmen çalışmanın başlangıç düzeyine göre daha iyi bir duruma gelindiği söylenebilir. Ali'nin okuduğunu anlamada yaşadığı problemler süreç içerisinde giderilmeye çalıșmış ve olumlu sonuçlar alınmıștır. Özellikle her oturumdan sonra metin hakkında Ali'ye yöneltilen sorular bu konuda fayda sağlamıştır. Ali'ye yöneltilen sorular basit anlama ve derin anlama düzeyini ölçecek türden sorulardan oluşmaktaydı.

Çalıșmanın bașlangıcında okuma ve okuduğunu anlamada endişe düzeyinde olan Ali, araştırmanın sonunda öğretim düzeyine ulașmıştır. Bu sonuçlardan hareketle bireyselleştirilmiş okuma programında uygulanan hızı kelime tanıma tabloları ile desteklenmiş nörolojik etki yönteminin okuma güçlüklerinin giderilmesinde etkili olduğu söylenebilir. Baştuğ ve Kaman (2013) tarafından yapılan benzer bir çalıșmada, dördüncü sınıfa devam eden farklı okuma düzeylerine sahip dokuz öğrenciler ile çalışılmış ve nörolojik etki yönteminin öğrencilerin akıcı okuma becerilerine ve okuduğunu anlama başarılarına katk sağladığı tespit edilmiştir. Ayrıca bu yöntemin, sadece okuma güçlüğü çeken öğrenciler üzerinde değil aynı zamanda orta ve üst düzey okuma becerisine sahip öğrenciler üzerinde de etkili olduğu belirlenmiștir.

Oladede (2013 ) tarafından yapılan başka bir çalışmada nörolojik etki yönteminin okuduğunu anlama üzerindeki etkisi belirlenmeye çalışılmıştır. Ilkokul dördüncü sınıfta okuma güçlüğü yaşayan öğrencilerle gerçekleştirilen çalışmada nörolojik etki yönteminin okuduğunu anlama becerisi üzerinde etkili olduğu sonucuna ulaşılmıștır. Okuma güçlüklerinin giderilmesine yönelik olarak 29 öğrenci ile yapılan bașka bir araștırmada nörolojik etki yönteminin okuma yeterliliklerinin artırılmasında etkili bir yöntem olduğu sonucuna ulaşmışlardır (Young vd., 2015).

Ziadat ve Awan (2018) tarafından 10-12 yas arasındaki 40 öğrencinin okuma güçlüklerinin giderilmesine yönelik olarak benzer bir çalışma yapılmıştır. Bu çalışmada kullanılan nörolojik etki yönteminin okuma güçlüklerinin giderilmesinde ve okuma akıcılığının sağlanmasında etkili olduğu sonucuna ulaşılmıştır. Young vd. (2018)'nin 57 ilkokul öğrencisi ile yaptıkları yedi haftalık deneysel bir çalışmada benzer sonuçlara ulaşılmıştır. Araştırmada nörolojik etki yönteminin okuma akıcılığı ve okuduğunu anlama üzerindeki etkisi incelenmiștir. Araștırma sonucunda nörolojik etki yönteminin ilkokul öğrencilerinin okuma akıcılığı ve okuduğunu anlama becerisinin geliştirilmesinde etkili olduğu sonucuna ulaşılmıştır.

Yapılan çalışmalar okuma güçlüğü yaşayan öğrencilere yönelik nörolojik etki yönteminin etkililiğini göstermektedir Özellikle hızlı kelime tanıma tablolarının bu yöntem ile birlikte kullanılması araştırmanın daha verimli geçmesini sağlamıştır.Hızlı kelime tanıma tabloları, öğrencide okunacak metne yönelik bir hazırbulunuşluk düzeyi oluşturmuş ve öğrencinin okumaya yönelik motivasyonunu artırmıştır. Öte yandan bir yöntemin etkili olmasında rol oynayan diğer faktörlerinde (planlama, kullanılacak materyaller, katılımcı düzeyi v.s.) unutulmaması gerekir. Aksi takdirde istenilen düzeyde bir başarı elde edilemeyebilir. Bu nedenle nörolojik etki yöntemi ile yapılacak çalışmalarda planlamaya, kullanılacak metinlerin seçimine ve katılımcıların motivasyon düzeylerine dikkat edilmelidir. Bundan sonra yapılacak benzer çalışmalarda nörolojik etki yöntemi, farklı yöntemlerle birlikte uygulanabilir. Nörolojik etki yönteminin daha üst sınıflarda uygulandığı benzer çalışmalar yapılarak etkililiği değerlendirilebilir. Hızı kelime tabloları ile başka yöntemlerin birlikte uygulandığı farklı çalışmalar yapılabilir Sınıf öğretmenlerine okuma güçlüklerinin giderilmesinde etkililiği kanıtlanmış yöntem ve tekniklerin tanıtıldığı hizmet içi eğitim seminerleri verilebilir. Ayrıca Milli Eğitim Bakanlığı bünyesinde okuma güçlüğü çeken öğrencilere yönelik ayr bir destek birimi oluşturularak daha profesyonel bir hizmet sunulabilir.

\section{Kaynakça}

Aktaș, E. ve Çankal, A. O. (2019). Akıcı okuma stratejilerinin 4. sınıf Türkçe derslerinde okuduğunu anlama becerisine ve okuma motivasyonuna etkisi. Zeitschrift Für Die Welt Der Türken/Journal of World of Turks, 11(1), 85-114.

Akyol, H. (2006a). Türkçe ilk okuma yazma öğretimi. Ankara: Pegem Akademi. 
Akyol, H. (2006b). Yeni programa uygun Türkçe öğretim yöntemleri. Ankara: Kök Yayıncılık.

Akyol, H. (2011). Türkçe öğretim yöntemleri (Yeni programa uygun). Ankara: Pegem Akademi Yayıncılık

Allington, R. L. (1983). Fluency: The neglected reading goal. Reading Teacher, 36(6), 556-561.

American Psychiatric Association. (2013). Diagnostic and statistical manual of mental disorders (DSM-5). Washington, DC: American Psychiatric Association.

Baker, T., \& Wigfield, A. (1999). Dimensions of children's motivation for reading and their relations to reading activity and reading achievement. Reading Research Quarterly, 34(4), 452- 477.

Başaran, M. (2013). Okuduğunu anlamanın bir göstergesi olarak akıcı okuma. Kuram ve Uygulamada Eğitim Bilimleri, 13(4), 2277-2290.

Baştuğ, M. (2012). Illköğretim 1. kademe öğrencilerinin akıcı okuma becerilerinin çeşitli değişkenler açısından incelenmesi (Yayınlanmamış doktora tezi). Gazi Üniversitesi, Ankara.

Baştuğ, M. ve Kaman, Ş.(2013). Nörolojik etki yönteminin öğrencilerin akıcl okuma ve anlama becerilerine etkisi. Mehmet Akif Ersoy Üniversitesi Eğitim Fakültesi Dergisi, 13(25), 291-309.

Demir, H. (2015). Yanlış analizi envanterinin ilkokul öğrencilerinin okumalarının değerlendirilmesinde kullanımı (Yayınlanmamıș yüksek lisans tezi). Hacettepe Üniversitesi, Ankara.

Demirel, Ö. (1999). Türkçe öğretimi. Ankara: Pegem Akademi Yayıncilık.

Ehri, L. C., \& McCormick, S. (1998). Phases of word learning: Implications for instruction with delayed and disabled readers. Reading \& Writing Quarterly: Overcoming Learning Difficulties, 14(2), 135-163. https://doi. org/10.1080/1057356980140202

Fielding-Barnsley, R. (2000). Reading disability: The genetics connection and appropriate action. http:// WWW.eric.ed.gov/contentdelivery/servlet/ ERICServlet?accno=ED447454 adresinden 02 Nisan 2019 tarihinde erişilmiştir.

Flood, J., Lapp, D., \& Fisher, D. (2005). Neurological impress method plus. Reading Psychology, 26(2), 147-160. https://doi.org/10.1080/02702710590930500

Gündüz, O. ve Şimşek, T. (2013). Uygulamalı okuma eğitimi el kitabı. Ankara: Grafiker.

Hasbrouck, J., \& Tindal, G. A. (2006). Oral reading fluency norms: a valuable assessment tool for reading teachers. Reading Teacher, 59(7), 636-644.

Kann, R. (1983). The method of repeated readings: expanding the neurological ımpress method for use with disabled readers. Journal of Learning Disabilities, 16(2), 90-92.

Kaşkaya, A. (2015). Beyin etkileme metodu destekli öğretim ile akıcı okuma ve okuduğunu anlamanın geliştirilmesi: Bir eylem araş̧ırması. Eğitim ve Bilim, 41(185), 281-297.
Keskin, H. K. (2012). Akıcı okuma yöntemlerinin okuma becerileri üzerindeki etkisi (Yayınlanmamış doktora tezi). Gazi Üniversitesi, Ankara.

Klauda, S. L., \& Guthrie, J. T. (2008). Relationships of three components of reading fluency to reading comprehension. Journal of Educational Psychology, 100(2), 310-321. https://doi.org/10.1037/00220663.100 .2 .310

Kuhn, M. R. (2005). A comparative study of small group fluency instruction. Reading Psychology, 26(2), 127146. https://doi.org/10.1080/02702710590930492

Lerner, J. (2000). Learning disabilities: Theories diagnosis and teaching strategies. New York: Huoghton Mifflin Comp.

Oladede, O. A. (2013). The efficacy of neurological impress method and repeated reading on reading fluency of childeren with learning disabilities in Oyo State, Nigeria. World Academy of Science, Engineering and Technology, International Journal of Social, Behavioral, Educational, Economic, Business and Industrial Engineering, 7, 187-190.

Pikulski, J. J., \& Chard, D. J. (2005). Fluency: Bridge between decoding and reading comprehension. The Reading Teacher, 58(6), 510-519. https://doi.org/10.1598/ RT.58.6.2

Stahl, S. A., \& Kuhn, M. R. (2002). Center for the Improvement of Early Reading Achievement: Making it sound like language: Developing fluency. The Reading Teacher, 55(6), 582-584.

Sucuoğlu, B., Diken, İ. H., Demir, S., Ünlü, E. ve Şen, A. (2010). Özel eğitim terimler sözlügü. Ankara: Maya Akademi.

Therrien, W. J., Gormley, S., \& Kubina, R. M. (2006). Boosting fluency and comprehension to improve reading achievement. Teaching Exceptional Children, 38(3), 2226. https://doi.org/10.1177/004005990603800303

Townsend, R. (1996). Reading wealth: Discover how to improve your reading and comprehension in six easy steps ( $T$. Keskin, Çev.). İstanbul: Sistem Yayıncılık.

Ülper, H. ve Yagmur, K. (2016). Doğru ve akıcı sessiz sözcük okuma testinin geliştirilmesi. Illköğretim Online, 15(2), 581-593. http://dx.doi.org/10.17051/io.2016.91112

Wang, J. H., \& Guthire, T. J. (2004). Modeling the effect of intrinsic motivation, extrinsic motivation, amount of reading, and past reading achievement on text comprehension between U.S. and Chinese students. Reading Research Quarterly, 39(2), 162-186. https:// doi.org/10.1598/RRQ.39.2.2

Yalçın, A. (2002). Türkçe öğretim yöntemleri -yeni yaklaşımlar-. Ankara: Akçağ.

Yıldırım, A. ve Șimșek, H. (2011). Sosyal bilimlerde nitel araştırma yöntemleri. Ankara: Seçkin Yayınları

Yıldı, M. (2013). Okuma motivasyonu, akıcı okuma ve okuduğunu anlamanın beşinci sınıf öğrencilerinin akademik başarılarındaki rolü. Turkish Studies International Periodical For The Languages, Literature and History of Turkish or Turkic, 8(4), 1461-1478. 
Yılmaz, M. (2008). Kelime tekrar tekniğinin akıcı okuma becerilerini geliştirmeye etkisi. Türk Eğitim Bilimleri Dergisi, 6(2), 323-350.

Young, C., Mohr, K. A. J., \& Rasinski, T. (2015). Reading together: A successful reading fluency intervention. Literacy Research and Instruction, 54(1), 67-81. https://doi.org/ $10.1080 / 19388071.2014 .976678$

Young, C., Pearce, D., Gomez, J., Christensen, R., Pletcher, B., \& Fleming, K. (2018). Read two impress and the neurological impress method: Effects on elementary students' reading fluency, comprehension, and attitude. The Journal of Educational Research, 111(6), 657-665. https://doi.org/10.1080/00220671.2017.139 3650

Ziadat, A. H., \& Al- Awan, M. S. A. (2018). The effectiveness of neurological impress method on reading fluency of students with learning disabilities in Amman, Jordan. International Education Studies, 11(1), 165-171. https:// doi.org/10.5539/ies.v11n1p165 